\title{
Perunan Y-viruksen levintä ja torjunta HG-siementuotantoalueella
}

\author{
Sascha Kirchner ${ }^{1,2}$, Lea Hiltunen ${ }^{2}$, Thomas Döring ${ }^{3}$, Jarmo Ketola ${ }^{4}$, Anu Kankaala ${ }^{2}$, Elina Virtanen ${ }^{2}$ ja \\ Jari Valkonen ${ }^{1}$ \\ ${ }^{1}$ Maataloustieteiden laitos, PL 27, 00014 Helsingin yliopisto \\ ${ }^{2}$ MTT Biotekniikka- ja elintarviketutkimus, PL 413, 90014 Oulun yliopisto \\ ${ }^{3}$ The Organic Research Centre, Elm Farm, Hamstead Marshall, Berkshire, RG 20 0HR, UK \\ ${ }^{4}$ MTT Kasvintuotannon tutkimus, 31600 Jokioinen
}

\section{Tiivistelmä}

Perunan Y-virus on kirvojen levittämä, yleisin ja haitallisin perunaa vaivaava virus. Y-viruksen leviämistä ei voi estää kemiallisin ruiskutuksin, joten torjunta perustuu terveen siemenperunan käyttöön ja kestävien lajikkeiden viljelyyn. Tällä vuosituhannella ongelmaksi on muodostunut Yviruksen uusi rotu, johon nykyisten lajikkeiden kestävyys ei tehoa. Uusi rotu on oireeton monissa perunalajikkeissa ja on siten pystynyt leviämään ympäri maailman ja yleistymään perunantuotantoalueilla. Ongelma havaittiin Suomessa 2000-luvun puolivälissä siementarkastuksen yhteydessä poikkeuksellisen pahoina Y-virussaastuntoina. Tutkimustulokset osoittivat uuden Yvirusrodun tulleen meilläkin vallitsevaksi. Siemenperunasta n. 75\% tuotetaan Pohjois-Pohjanmaalla. Tyrnävän ja Limingan pellot muodostavat erityisen korkealaatuisen siemenperunan tuottamiseen sopivan alueen (High Grade Seed Potato Production Zone), jolla on Euroopan Unionin hyväksyntä. Erityisasema perustuu EU:n kasvinsuojelulainsäädännön tuntemien, perunalle vaarallisten kasvintuhoojien puuttumiseen. Vastaavia alueita on muualla Euroopassa vain neljä: Pohjois-Saksassa, Skotlannissa, Irlannissa ja Azorien saarilla Portugalissa. Y-virusongelmien levittyä siementuotantoon kotimainen ruoka- ja teollisuusperunantuotantokin olivat vaarassa siemenpulan takia. Siten Y-viruksen leviämisen ja torjunnan selvittämiseen HG-alueella tarvittiin tutkimusta, johon myös siemenperunaa tuottavat yhtiöt ja sopimusviljelijät osallistuivat. HG-alueen perunaviljelyksiltä (6 tai 7 peltoa/kasvukausi) pyydystettiin kirvoja kelta-ansoilla vuosina 2007-2009. Pyydystys aloitettiin juuri ennen perunan taimettumista ja sitä jatkettiin sadonkorjuuseen asti. Ansat koettiin kaksi kertaa viikossa. Kirvojen määrä laskettiin ja lajit määritettiin. Heti taimettumisen jälkeen taimista testattiin Y-virus kasvuston lähtökohtaisen Y-virussaastunnan selvittämiseksi. Myös sato testattiin, jotta Yviruksen kertautuminen kasvukauden aikana voitiin määrittää. Kolmen kasvukauden aikana pyydystettiin 30,788 kirvaa, jotka tunnistettiin yksitellen. Ne edustivat yli 80 lajia, joista yhdeksän on aiemmissa tutkimuksissa havaittu Y-viruksen levittäjiksi (vektoreiksi). Tärkeimpien vektorilajien määrittämiseksi vertailtiin käytettävissä olevia tuloksia ja taustatietoja Akaike'n kriittiseen informaationtarkasteluun perustuvalla menetelmällä. Parhaiten Y-viruksen kertautumista selittäviä muuttujia käytettiin sen jälkeen tärkeimmän vektorilajin tunnistamiseen mallinnuksen avulla. Papu- eli juurikaskirvan (Aphis fabae) esiintyminen runsain määrin heti taimettumisen jälkeen selitti yksinään Y-viruksen kertautumisen. Muilla kirvalajeilla ei ollut mainittavaa merkitystä. Taimettumisvaiheessa kirvojen laskeutumista kasveille voidaan ehkäistä katteiden avulla, sillä paljaan maan peittävä kate vähentää lentävän kirvan mahdollisuutta erottaa yksittäisiä kasveja taustasta. Myös mineraaliöljyruiskutukset lehdille ehkäisevät kirvojen viruslevitystä. Kummallakin menetelmällä voitiin vähentää Y-viruksen kertautumista 50-60\%, kun taas kirvatorjunta-aineilla ei havaittu vaikutusta Y-viruslevintään. 


\section{Johdanto}

Perunan Y-virus (PVY) on kirvojen levittämä, maailmanlaajuisesti merkittävin virustaudinaiheuttaja perunassa (Radcliffe \& Ragsdale 2002, Valkonen 2007). PVY:n aiheuttamat ongelmat ovat lisääntyneet kaikilla pohjoisen pallonpuoliskon perunantuotantoalueilla 2000-luvulla.

Suomessa Y-viruksen yleisyys perunan siementuotannossa alkoi hälyttävästi lisääntyä vuodesta 2002 lukien. Sen jälkeen siemeneriä on hylätty tai niiden luokkaa jouduttu laskemaan Y-viruksen takia huomattavasti useammin kuin kahtena edellisenä vuosikymmenenä. Y-virustilanteen paheneminen osoitti, että perunan siementuotantoketjussa tarvittiin pikaisia korjaustoimenpiteitä, joilla tilanteen huononeminen saataisiin pysäytettyä ja ongelmien lähteet poistettua. Koska virustilanne oli maassamme aiemmin jatkunut hyvänä pitkään, Y-virusta oli tutkittu hyvin vähän ja tiedot Y-virusta levittävistä kirvoista, levinnän ajankohdasta siementuotantoalueilla, nykyisistä Y-virusroduista sekä nykyisten lajikkeiden kestävyydestä niille puuttuivat.

Tämän hankkeen tavoitteena oli tuottaa Y-viruksen torjunnan tehostamista varten tarvittavat perustiedot. Tutkimus kohdistui siemenperunatuotannon High Grade-alueeseen Pohjois-Pohjanmaalla, jossa yli 70\% maamme siemenperunan viljelystä tapahtuu. Tutkimuksen toteuttivat Helsingin yliopiston Kasvipatologian laboratorio, MTT Oulu ja MTT Kasvintuotannon tutkimus (Kasvinsuojelu) tiiviissä yhteistyössä siemenperuna-alan toimijoiden ja Elintarviketurvallisuusvirasto Eviran kanssa. Rahoittajina olivat Maa- ja metsätalousministeriö sekä siemenperuna-alan yritykset.

\section{Aineisto ja menetelmät}

HG-alueella viljellystä sadosta saatiin Y-virusnäytteet Eviran välityksellä sertifiointiin lähetetyistä siemenperunaeristä. Y-virusrodut tunnistettiin monoklonaalisilla virusvasta-aineilla sekä määrittämällä virusten kuoriproteiinia koodaavan genomialueen RNA-sekvenssi ja vertaamalla sitä tietokannoissa oleviin sekvensseihin fylogeneettisin menetelmin. Lajikkeiden vasteet suomalaiselle Y-viruksen NTNrodulle testattiin kasvihuoneessa varttotartutuksella.

Kirvoja pyydystettiin keltamaljoilla kolmen kasvukauden ajan (2007-2009) HG-alueella. Maljat koettiin kahdesti viikossa. Kasvukauden aikana laskettiin saaliin määrä ja tiedotettiin viljelijöitä kirvaesiintymistä viikoittain. Kaikki pyydystetyt kirvat tunnistettiin yksitellen talvikautena. Vuosittain tutkittavana oli 6-9 siemenviljelylohkoa.

Lohkoilta, joilla kirvaseuranta suoritettiin, määritettiin perunoiden Y-viroottisuus heti kasvien tullessa taimelle kesä-heinäkuun vaihteessa. Muutamaa viikkoa myöhemmin testattiin Y-virusta kasvien lehdistä. Noston jälkeen testattiin sadon Y-viroottisuus idätettyjen mukuloiden taimista.

Osaruutukenttäkokeissa testattiin mineraaliöljyn, erilaisten kirvatorjunta-aineiden sekä olkikatteen vaikutusta Y-viruksen levintään kasvukautena.

\section{Tulokset ja tulosten tarkastelu}

Siemenperunatuotannossa esiintyvien Y-virusrotujen havaittiin kuuluvan pääasiassa (60 \%) uuteen NTN-tyyppiin, joka on yleistynyt kaikilla perunantuotantoalueilla maailmassa. Sen aiheuttamat oireet vaihtelivat ankaruudeltaan testatuissa 29 perunalajikkeessa. Osa lajikkeista oli oireettomia, osassa aiheutui lehtimosaiikkia ja kasvuhäiriöitä, ja osassa virus aiheutti nekroosia ja ankaraa kasvun taantumista. Myös NTN-tyypille ominaisia kuolioita ja halkeamia syntyi joidenkin lajikkeiden mukuloihin.

Y-virustestauksessa käytettyjen vasta-aineiden sitoutumiskohdat viruksen kuoriproteiinissa selvitettiin. Tiedon avulla pystyttiin kansainvälisten tietokantojen aineistoista ennustamaan uusien, testauksista huomaamattomasti läpipääsevien viruskantojen esiintymisriskiä. 


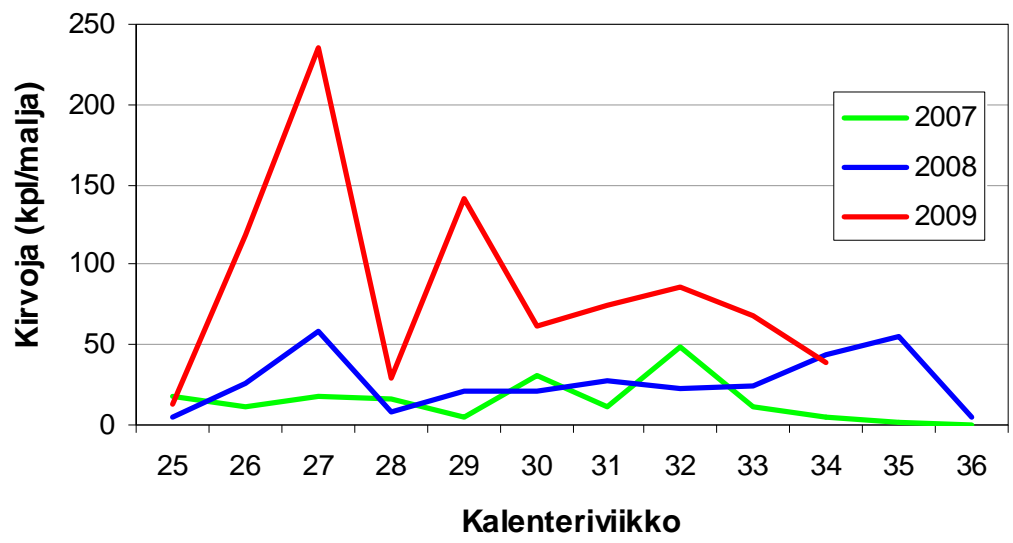

Kuva 1. Siemenperunalohkoilta pyydystettyjen kirvojen lukumäärä keltamaljoissa viikoittain 2007-2009. Kunakin vuonna tutkimuksenalaisia lohkoja oli 6-8. Keltamaljat tarkastettiin kahdesti viikossa.

Kaikkiaan High Grade-alueen perunapelloilla havaittiin vierailevan yli 80 kirvalajia. Niistä mikään ei asuttanut perunaa. Kirvojen esiintymisessä toistui säännöllinen 3-vuotinen kannanvaihtelu (Kuva 1). Y-viruksen kertautumiseen johtaneet tartunnat siemenperunakasvustoissa tapahtuivat kahden viikon kuluessa perunan taimelle tulosta. Sitä myöhäisempi kirvojen esiintyminen kasvustoissa ei enää merkittävästi lisännyt sadon Y-viroottisuutta. Tärkeimmäksi Y-viruksen levittäjäksi tunnistettiin juurikas- eli papukirva (Kirchner ym. 2011). Ottaen kirvayksilöiden määrä, kirvalajien suhteellinen teho Y-viruksen levittäjinä sekä istutuksessa käytetyn siemenperunan Y-virussaastunta-aste huomioon pystyttiin tulevan sadon Y-viroottisuus ennustamaan hyvin tarkasti jo heinäkuussa (Kirchner ym. 2011).

HG-alueen peltoalueiden kesken havaittiin eroja Y-viruksen levintäpaineessa. Y-viruksen kertautuminen High Grade-alueen perunakasvustoissa oli kuitenkin kokonaisuudessaan huomattavasti hillitympää kuin Etelä-Suomen pelloilla (Jokioinen ja Helsinki).

Hankkeessa tutkittiin Euroopan Unionin hyväksymän, suomalaisen HG-siementuotantoalueen kirvalajistoa ja Y-viruksen kertautumista nykyisissä perunantuotanto-oloissa, jotka poikkeavat monilta osin niistä, joissa Y-viruksen leviämiseen liittyviä tutkimuksia on tehty aiemmin (Radcliffe \& Ragsdale 2002). Erityisesti kasvukauden lyhyys toiminee merkittävänä kirvapaineen vähentäjänä ja siten Y-viruksen leviämisen hillitsijänä, sillä kirvoilla on vain vähän aikaa lisääntyä kesäisännillään.

Tutkimuksen tuottamia tietoja tarvitaan Y-viruksen paremman hallinnan ja tehokkaamman torjunnan perustaksi. Muilla perunantuotantoalueilla kautta maailman yleisimmäksi havaittu NTNvirusalarotu osoittautui Suomenkin HG-alueella yleisimmäksi. Tästä voidaan päätellä, että se on nykyisin koko maamme perunatuotannossa yleisin Y-virustyyppi, sillä suurin osa siemenperunasta tuotetaan Pohjois-Pohjanmaalla. PVY-NTN aiheutti lajikkeissa vaihtelevia oireita, aina oireettomuudesta ankariin kuolio-oireisiin lehdissä, varsissa ja mukuloissa, kuten muuallakin on todettu (Singh ym. 2008).

Tuloksia selostettiin viljelijöille pellonpiennartilaisuuksissa sekä viljelijäseminaareissa. Oireet myös valokuvattiin ja järjestettiin internet-tietokannaksi, joka on vapaasti nähtävillä.

Y-viruksen tärkeimmäksi levittäjäksi todettiin papu- eli juurikaskirva kenttätutkimuksien ja kirvalajimääritysten avulla. Tulos poikkeaa aiemmin esitetystä arviosta, jonka mukaan tuomikirva olisi merkittävä Y-viruksen levittäjä (Kurppa \& Rajala 1986). Myös Y-viruksen tärkein leviämisajankohta voitiin selvittää ja tunnistaa kasvukauden alussa tapahtuvan ensimmäisen kirvainvaasion aiheuttamaksi. Tilastollinen mallinnusmenetelmä (Kirchner ym. 2011), jolla johtopäätöksiin tultiin, on merkittävästi kehittyneempi kuin Y-viruksen epidemiologian tutkimuksissa aikaisemmin käytetyt lähestymistavat (Sigvald 1990).

Peruna toimii HG-alueella keskeisenä Y-viruslähteenä. Useilla siemenperunaviljelmien havaintolohkoilla siemenperunassa oli Y-virusta sertifioidun siemenen A-luokan sallimissa rajoissa. 
Alueella on kuitenkin myös muuta perunatuotantoa, jossa voidaan käyttää tilan omaa satoa siemenenä yhtenä kasvukautena ennen siemenen uusimista. Tällöin viljelyyn käytetään myös A-luokkaa viroottisempaa siemenperunaa. Tutkimuksessa havaittiin, että osalla tiloista Y-virussaastunta sadossa ylitti $20 \%$ ja oli joissain tapauksissa erittäin korkea.

Tietojen perusteella pystytään suunnittelemaan tehostettuja torjuntatoimia. Niistä tärkein on viroottisen siemenperunan käytön vähentäminen HG-alueella. Maan kattamista oljella taimivaiheessa sekä lehvästön mineraaliöljyruiskutuksia voidaan käyttää hillitsemään kirvojen vierailua kasvustoissa (Saucke \& Döring 2004). Näillä keinoin voitiin PVY-saastuntaa vähentää puoleen HG-alueella tehdyissä kenttäkokeissa.

Y-viruksen kertautumisen ennustaminen antaa mahdollisuuden suunnitella siemenviljelyksen sadon käyttötarkoitusta jo kasvukauden aikana. Nykyisten käytänteiden valossa ennuste voisi tukea esim. päätöstä siemenen sertifioimiseksi B-luokkaan, jos Y-virussaastunta uhkaa nousta odotettua korkeammaksi. Ennusteen käyttötarkoituksia tulisi harkita, kun sen luotettavuudesta on saatu lisätietoa jatkotutkimuksissa.

\section{Johtopäätökset}

Tutkimus tuotti runsaasti tietoa Y-viruksen paremman hallinnan ja tehokkaamman torjunnan perustaksi. Uuden ja yleisimmäksi osoittautuneen NTN-virustyypin oireet tärkeimmissä lajikkeissa selvitettiin, selostettiin viljelijöille pellonpiennartilaisuuksissa, ja valokuvattiin internet-tietokantaan, jossa siemenalan toimijat voivat tutustua niihin tarvittaessa. Y-viruksen levittäjänä tärkein kirvalaji saatiin selville, samoin kuin levinnän tärkein ajankohta kasvukautena. Tulosten perusteella voidaan perunaa itseään pitää ainoana merkittävänä Y-viruslähteenä High Grade-alueella. Tietojen perusteella pystytään myös suunnittelemaan tehostettuja torjuntatoimia. Sellaisia voivat olla myöhästetty istutus, jolloin perunat eivät ole taimella, kun tehokkaimmin Y-viruksen leviämiseen johtava kirvojen vierailu tapahtuu perunapelloilla kesä-heinäkuun vaihteessa, tai olkikatteen levitys ja muut käsittelyt, joilla hillitään kirvojen vierailua kasvustoissa. Y-viruksen kertautumisen ennuste tuo mahdollisuuden suunnitella sadon käyttötarkoitusta uudelleen jo kasvukauden aikana, ennen siemensadon sertifiointia. Tähän on tarvetta, jos hankkeessa osoitettujen, yksinkertaisesti toteuttavien havaintojen perusteella Yvirustartunta on muodostumassa liian korkeaksi kaikista toimista huolimatta.

\section{Kirjallisuus}

Kirchner, S.M., Döring, T.F., Hiltunen, L.H., Virtanen, E. \& Valkonen, J.P.T. 2011. Information theorybased model selection for determining the main vector and period of transmission of Potato virus $Y$ in potato crops. Annals of Applied Biology 159: 414-427.

Kurppa, S. \& Rajala, P. 1986. Occurrence of winged aphids on potato plants and pressure for potato virus $Y$ transmission in Finland. Annales Agriculturae Fenniase 25: 199-214.

Radcliffe, E.B. \& Ragsdale, D.W. 2002. Aphid-transmitted viruses: the importance of understanding vector biology. American Journal of Potato Research 79: 353-386.

Saucke, H. \& Döring, T.F. 2004. Potato virus $Y$ reduction by straw mulch in organic potatoes. Annals of Applied Biology 144:347-355.

Sigvald, R. 1990. Aphids on potato foliage in Sweden and their importance as vectors of potato virus $\mathrm{Y}^{\mathrm{O}}$. Acta Agriculturae Scandinavica 40:53-58 .

Singh, R.P., Valkonen, J.P.T., Gray, S.M., Boonham, N., Jones, R.A.C., Kerlan, C. \& Schubert, J. 2008. Discussion paper: The naming of Potato virus $Y$ strains infecting potato. Archives of Virology 153:1-13.

Valkonen, J.P.T. 2007. Potato viruses: economical losses and biotechnological potential. Teoksessa: R. Viola, C. Gebhardt, F. Govers, D. Vreugdenhil \& D. MacKerron (toim.). Potato Biology and Biotechnology. Elsevier. s. 619-641. 